\title{
DOMINANT ATTRIBUTE OF MANGO INDOOR FRAGRANCE
}

\section{ATRIBUT DOMINAN PEWANGI RUANGAN RUANGAN DARI MANGGA}

\author{
Yosini Deliana $^{1 *}$, Sri Fatimah ${ }^{1}$, Mohamad Djali ${ }^{2}$ \\ ${ }^{1}$ Department of Agribusiness, Faculty of Agriculture, Universitas Padjadjaran, \\ Jatinangor 45363, Indonesia \\ ${ }^{2}$ Department of Food, Faculty of Agroindustrial Technology, Universitas Padjadjaran, \\ Jatinangor 45363, Indonesia \\ *Email: y.deliana@gmail.com,
}

(Diterima 26-10-2019; Disetujui 18-11-2019)

\begin{abstract}
Mango produced from Cirebon, Indramayu and Sumedang have different qualities. Those types of mango is already has its own market segment. The on farm problem is mango producers do not know exactly how consumer preferences for mango from Cirebon, Indramayu and Sumedang. When the harvest time, over supply and mango price getting decrease. The idea to solve this problem is to process mango over supply become mango indoor fragrance. Variables that distinguish consumer preference are easy to find, aroma, colour, duration, freshness, water content, expire date, purpose, information and additional esens. The purpose of this study to analysis respondent's characteristics, dominant attribute of mango indoor fragrance which are the least dominant attribute of these product.
\end{abstract}

Keywords: Mango central Production, attribute of mango indoor fragrance, Kruskal-Wallis test, simple random sampling

\begin{abstract}
ABSTRAK
Mangga yang diproduksi Cirebon, Indramayu dan Sumedang memiliki beberapa kualitas. Semua tipe mangga memiliki segmen pasar tersendiri. Masalah yang terjadi di hulu adalah produsen tidak mengetahui dengan pasti apa yang diinginkan konsumen dari Cirebon, Indramayu dan Sumedang. Pada saat panen terjadi over produksi dan harga mangga turun. Ide untuk memecahkan masalah ini adalah mengolah kelebihan mangga menjadi pewangi ruangan. Variabel yang membedakan selera konsumen dalam memilih pewangi mangga adalah kemudahan dalam mendapatkan pewangi mangga, aroma, warna, ketahanan dari wangi mangga, kesegaran, kandungan air, kadalurawsa, kegunaan, informasi dan tambahan esen pewangi lainnya.
\end{abstract}

Kata kunci: Sentra produksi mangga, attribute pewangi mangga, test Kruskal-Wallis, sampel acak sederhana

\section{INTRODUCTION}

Almost all agricultural products are easily damaged, as well as Mangga (Mangifera indica L). At harvest time between October and November, mango production is abundant. Indramayu Regency, the largest mango producer in West Java reached 34,999 tons or about
$13 \%$ of the total production of West Java (Agriculture and Livestock Service Office of Indramayu District, 2014). The mango production from Indramayu is devoted to the processing of mango indoor fragrances, while other production centers are focused on fresh and puree mango. Mango is great for diet because it contains 
provitamin A Carotenoids, Vitamin C, and phenolics.

To increase the added value of mangoes and extend mango storage, wider market reach and less risk of damage, mangoes are salted into sweets of mango indoor fragrances. Mango indoor fragrance can be done with extract technology. Some research results on the technology of drying the fruit carried out such as drying 'mango leather. This study analyzes what factors determine consumer in buying mango indoor fragrance.

Purchasing decisions are consumers' decisions about what they want to buy, how much to buy, where to do, when to do, and how they will be purchased. Purchase decision process is the stages that the buyer passes in determining the choice of products and services to be purchased. Other experts claim that consumer decision making is a combined process of integration.

The decision as a selection of two or more alternative options, in other words the availability of more than one choice is a must in decision making. The buying decision process refers to the consistent and thoughtful actions taken to meet the needs. There are five stages: (1) recognition of needs, (2) information search, (3) alternative evaluation, (4) purchasing decision, and (5) post purchase behavior.

Many factors influence consumer decisions in the decision process, there are internal and external factors. In addition, there are three categories of factors that affect consumers in purchasing products that are personal factors, psychological and social factors, in addition to cultural factors. The next group factor can be labelled as situational factors, it means factors forming the environment of the concrete decision making situation As a personal factors, there are referred the one a unique for each consumer. Above all data like age, sex, place of domestic, occupational and economics conditions, personality and self-consciousness. Psychological factors include motivation, perception, skills and knowledge, position, personality, style of life. Situational factors can notably influences purchase decision. Social environment, physical environment of the purchase place, time influences and the previous states fall into this group.

\section{RESEARCH METHODS}

The study was conducted in March June 2019 at three location of Bandung which material mango indoor fragrance from central production Indramayu, 
Cirebon and Sumedang. The data in this research are primary and secondary data while sampling technique is systematic random sampling for 100 respondents.

Systematic Sampling is another useful alternative for sampling with a large sample population. Systematic sampling is a method where only the first element of the sample is randomly chosen while the subsequent elements are systematically selected according to a particular pattern.

Technique of collecting data is done by observation, interview, questioner and literature study. The purpose of this study is to determine what factors determine consumer decisions in mango indoor fragrance purchases. Data were analyzed by Kruskal-Walls one way analysis.

Kruskal-Wallis Test as follow:

1. Without double data

$$
K W=\frac{12}{N(N+1)} \sum_{i=1}^{k} \frac{R_{j}^{2}}{n_{j}}-3(N+1)
$$

2. With double data

$$
K W=\frac{\frac{12}{N(N+1)} \sum_{i=1}^{k} \frac{R_{j}^{2}}{n_{j}}-3(N+1)}{1-\left(\frac{\sum t_{j}\left(t_{j}^{2}-1\right)}{N\left(N^{2}-1\right)}\right)}
$$

\section{Test Criteria:}

1. for treatment $\leq 3$
Reject $\mathrm{H}_{0}$ if $K W_{\text {count }} \geq K W_{\text {table }}$ and accept $\mathrm{H}_{0}$ otherwise. Use table $\mathrm{O}$.

2. for treatment $>3$

Reject $\mathrm{H}_{0}$ if $\chi_{\text {count }}^{2} \geq \chi^{2}{ }_{\alpha}$, df $=\mathrm{k}-1$, receive in other case. Use Chi-Square Table

\section{Hypotheses:}

$\mathrm{H}_{0:} \mu_{\mathrm{u}}=\mu_{\mathrm{v}}$

$\mathrm{H}_{0:} \mu_{\mathrm{u}} \neq \mu_{\mathrm{v}}$

Reject $\mathrm{H}_{0}$ if

$\left|\bar{R}_{A}-\bar{R}_{B}\right| \geq Z_{\left(\frac{\alpha}{2(k-1)}\right)} \sqrt{\frac{N(N+1}{12}\left(\frac{1}{N_{A}}+\frac{1}{N_{B}}\right)}$

continue next test for all treatment.

\section{RESULTS AND DISCUSSION}

\section{Respondents' Characteristics}

The respondents who bought mango indoor fragrance were generally 41-50 years old, female, the job was entrepreneur, the graduate education and the salary between 5-10 milliard rupiah / month. High income i have something to do with willingness to pay. For the middle to upper class the price of expensive mango indoor fragrance is not a problem, because this group is more concerned with quality. Thus with the increase in income then the quality of goods purchased increased, not buy the same goods with more number. Characteristics of consumers can be seen in Table 1 . 
Table 1. Responden's Characteristics

\begin{tabular}{lll}
\hline Variable & Description & \% \\
\hline Year & $<30$ & 12 \\
& $30-40$ & 27 \\
& $41-50$ & 46 \\
Gender & $>51$ & 15 \\
& Male & 39 \\
Occupation & Female & 61 \\
& Civil servant & 23 \\
& Entrepreneur & 47 \\
Education & Private & 30 \\
& High School & 25 \\
& Diploma & 21 \\
& Graduate & 41 \\
Income & Post Graduate & 13 \\
(Rp/month) & $<5$ million & 27 \\
& & \\
& 5 -10 million & 38 \\
& $>15$ million & 35 \\
\hline
\end{tabular}

Table 2. Comparison Test of Kruskal Wallis for Attribute Mango indoor fragrance from Indramayu

Test Statistics $^{a, b}$

\begin{tabular}{|l|r|}
\hline & Indramayu \\
\hline Chi-Square & 113,678 \\
df & 9 \\
Asymp. Sig. &, 000 \\
\hline
\end{tabular}

a. Kruskal Wallis

Test

b. Grouping

Variable: Atribut

Based on the results of the analysis above shows that the average comparison test results using Kruskal Wallis obtained p-value of $0,000<0,05$, then $\mathrm{H}_{0}$ is rejected. This shows that there is a significant difference between Artibut on Indramayu Mango.

From the results of the above analysis also seen that for Mangga Indramayu, the meaning sequence of the greatest Mean Rank is preference are easy to find, aroma, colour, duration, freshness, water content, expire date, purpose, information and additional esens. This indicates that for Mango Indramayu, the sequence of meaning from the most prominent is preference are easy to find, aroma, colour, duration, freshness, water content, expire date, purpose, information and additional esens.

Table 3. Comparison Test of Kruskal Wallis for Attribute on Cirebon Mango

$$
\begin{array}{|l|r|}
\hline \multicolumn{2}{|c|}{\text { Test Statistics }^{\text {a,b }}} \\
\hline \text { Chi-Square } & \text { Cirebon } \\
\text { df } & 82,399 \\
\text { Asymp. Sig. } & , 000 \\
\hline \multicolumn{2}{|c|}{\text { a. Kruskal Wallis }} \\
\text { Test } \\
\text { b. Grouping } \\
\text { Variable: Atribut }
\end{array}
$$

Based on the results of the analysis above shows that the average comparison test results using Kruskal Wallis obtained p-value of $0,000<0,05$, then $\mathrm{H}_{0}$ is rejected. This shows that there is a significant difference between Artibut on Mango Cirebon.

From the results of the above analysis also shows that for Mangga Cirebon, the meaning sequence of the greatest Mean Rank is preference are easy to find, aroma, colour, duration, freshness, water content, expire date, purpose, information and additional esens. This indicates that for Mango Cirebon, the most prominent sequence of meaning 
preference are easy to find, aroma, colour, duration, freshness, water content, expire date, purpose, information and additional esens.

Table 4. Comparison Test of Kruskal Wallis for Attribute on Mango Indoor Fragrance Test Statistics ${ }^{a, b}$

\begin{tabular}{|l|r|}
\hline & \multicolumn{1}{|c|}{ Import } \\
\hline Chi-Square & 139,305 \\
df & 9 \\
Asymp. Sig. &, 000 \\
\hline
\end{tabular}

a. Kruskal Wallis Test

b. Grouping Variable: Atribut

Based on the results of the analysis above shows that the average comparison test results using Kruskal Wallis obtained p-value of $0,000<0,05$, then $\mathrm{H}_{0}$ is rejected. This shows that there is a significant difference between Artibut on Mango from Sumedang.

From the results of the above analysis also seen that for Mango Sumedang, the meaning sequence of the greatest Mean Rank is preference are easy to find, aroma, colour, duration, freshness, water content, expire date, purpose, information and additional esens. This indicates that for Mango Sumedang, the most prominent sequence of meaning is preference are easy to find, aroma, color, duration, freshness, water content, expire date, purpose, information and additional esens. Thus for the whole attribute of candied mango indoor fragrance from Cirebon, Indramayu and Import are as follows:

Table 5. Sequence Mango indoor fragrance Attributes from, Indramayu, Cirebon and Sumedang

\begin{tabular}{lccc}
\hline \multicolumn{1}{c}{ Attribute } & $\begin{array}{c}\text { Sequence Mango from } \\
\text { Indramayu }\end{array}$ & $\begin{array}{c}\text { Sequence Mango from } \\
\text { Cirebon }\end{array}$ & $\begin{array}{c}\text { Sequence Mango from } \\
\text { Sumedang }\end{array}$ \\
\hline Easy to find & 3 & 2 & 5 \\
Aroma & 3 & 4 & 10 \\
Color & 6 & 5 & 3 \\
Duration & 1 & 1 & 5 \\
Freshness & 5 & 6 & 7 \\
Water content & 8 & 7 & 4 \\
Expire date & 2 & 3 & 2 \\
Purpose & 9 & 9 & 9 \\
Information & 7 & 8 & 8 \\
Additional Essens & 4 & 4 & 6 \\
\hline
\end{tabular}

From the results of the study revealed that, consumers $(87 \%)$ said the mango indoor fragrance flavor from Sumedang better than mango indoor fragrance from Indramayu and Cirebon, because it is more aroma, duration, less water contens, and additional essens. The weakness of mango indoor fragrance from Indramayu, Cirebon compare to mango indoor fragrance from Sumedang are those factots that should be improved. 


\section{CONCLUSION}

1. Consumers who like local or import mango indoor fragrance are adults, women, entrepreneurs, educated and income 5- 10 million per month.

2. Dominant attribute of mango indoor fragrance among mango from Indramayu, Cirebon and Sumedang are more arome, duration, less water contens, and additional essens..

3. The least dominant attributes of mango Sumedang is color.

\section{SUGGESTION}

To improve the quality of mango indoor fragrance, it is necessary to do research in collaboration with food technology experts.

\section{REFERENCES}

Deliana, Yosini, Sri Fatimah, Anne Charina (2018). The push factors of producers mango in using label as part of customer service marketing. Reserach Journal of Recent Sciences 7 (10). 10-13 .

Baloch, F. S., Tahir, S. S., Sherazi, S. T. H., Jilani, N. S., Khokhar, A. L., \& Rajput, M. T. (2017). Evaluation of essential oil components from the fruit peelings of sindhri and langra varieties of mango (mangifera indica L.). Pak. J. Bot, 49(4), 14791484.

Brown A. Chapter Class Note. edul.edu. http://www.edul.edu/alex/chap6.ht ml. Published 2006.

D [zbreve] amić, A. M., Marin, P. D.,
Gbolade, A. A., \& Ristić, M. S. (2010). Chemical composition of Mangifera indica essential oil from Nigeria. Journal of Essential Oil Research, 22(2), 123125.Berkowitz. EN, Kerin. RA, Hartley SW. 2010. Marketing (6th $E d)$. New York: Mc Graw-Hill.

E. Olobatuy. M. A User's Guide to Path Analysis. University Press of America: Social Science; 2006.

Engel JF, D.Blackwell R, W.Miniard. P. Consumer Behavior. Dryden Press Series In Marketing

Horska E, Sparke K. Marketing atitudes towards the functional food and implications for market segmentation. Agric Econ - Czech. 2007;53:349-353.

Kotler P, Kevin Lane Keller. 2012. Marketing management. Pearson Educ Ltd. 2012;817:1.

Koudelka J. Spotrebni Chovani a Marketing (Consumer Behavior and Marketing). Graha, Praha; 1997.

Lamb CW, Hair JF, Calhoun JW, Marquardt N, Bryant J, Shirley SJ. Essential of Marketing.; 2009.

Omolo, M. V. (2015). Essential oil chemistry of some Mangifera indica varieties from Kenya.

Shiffman. LG, L.L K. Consumer Behavior (9th Ed). New Jersey: Printice Hall; 2010.

Sogi DS, Siddiq M, Roidoung S, Dolan KD. Total Phenolics, Carotenoids, Ascorbic Acid, and Antioxidant Properties of Fresh-cut Mango ( Mangifera indica L ., cv . Tommy Atkin ) as Affected by Infrared Heat Treatment. 2012;77(11):1197-1202. doi:10.1111/j.17503841.2012.02933.x

Vysekalová J. Psychologie Spotřebitele: Jakzákazníci Nakupuji (Consumers Psychology: How Do the Customer Shop ? 1st editio. Praha: GR ADA Publishing; 2004. 
MIMBAR AGRIBISNIS

Jurnal Pemikiran Masyarakat Ilmiah Berwawasan Agribisnis. Januari 2020. 6(1): 120-127

\section{Appendix}

\section{Attribute of Indramayu Mango indoor fragrance}

\section{Ranks}

\begin{tabular}{|c|c|c|c|}
\hline \multirow[t]{12}{*}{ Indramayu } & Attribute & $\mathrm{N}$ & $\begin{array}{l}\text { Mean } \\
\text { Rank }\end{array}$ \\
\hline & Easy to find & 100 & 567,92 \\
\hline & Aroma & 100 & 260,76 \\
\hline & Colour & 100 & 496,16 \\
\hline & Duration & 100 & 634,17 \\
\hline & Freshness & 100 & 511,22 \\
\hline & $\begin{array}{l}\text { Water } \\
\text { contens }\end{array}$ & 100 & 489,74 \\
\hline & Expire date & 100 & 579,53 \\
\hline & Purpose & 100 & 453,16 \\
\hline & Information & 100 & 492,28 \\
\hline & $\begin{array}{l}\text { Additional } \\
\text { esens }\end{array}$ & 100 & 520,09 \\
\hline & Total & 1000 & \\
\hline
\end{tabular}

\begin{tabular}{|l|r|}
\multicolumn{2}{|c|}{ Test Statistics $^{\mathrm{a}, \mathrm{b}}$} \\
\hline & Indramayu \\
\hline Chi-Square & 113,678 \\
df & 9 \\
Asymp. Sig. &, 000 \\
\hline
\end{tabular}

a. Kruskal Wallis Test

b. Grouping Variable: Atribut

\section{Attribute of Cirebon Mango indoor fragrance}

\begin{tabular}{|c|c|c|c|}
\hline \multicolumn{4}{|c|}{ Ranks } \\
\hline \multirow[t]{13}{*}{ Cirebon } & Attribute & $\mathrm{N}$ & Mean \\
\hline & & & Rank \\
\hline & Easy to find & 100 & 561,28 \\
\hline & Aroma & 100 & 280,25 \\
\hline & Colour & 100 & 511,65 \\
\hline & Duration & 100 & 591,47 \\
\hline & Freshness & 100 & 507,42 \\
\hline & Water contens & 100 & 505,20 \\
\hline & Expire date & 100 & 538,73 \\
\hline & Purpose & 100 & 466,47 \\
\hline & Information & 100 & 504,19 \\
\hline & $\begin{array}{l}\text { Additional } \\
\text { esens }\end{array}$ & 100 & 538,37 \\
\hline & Total & 1000 & \\
\hline
\end{tabular}

\begin{tabular}{|l|r|}
\multicolumn{1}{|l|}{ Test Statistics $^{\mathrm{a}, \mathrm{b}}$} \\
\hline \multicolumn{1}{|l|}{ Chi-Square } & \multicolumn{1}{|c|}{ Cirebon } \\
df & 82,399 \\
Asymp. Sig. & 9 \\
\hline \multicolumn{2}{|c|}{, 000} \\
\hline \multicolumn{2}{|c|}{ a. Kruskal Wallis } \\
Test \\
b. Grouping \\
Variable: Atribut
\end{tabular}


Attribute of Sumedang Mango indoor fragrance

\section{Ranks}

\begin{tabular}{llll}
\hline Import & Attribute & $\mathrm{N}$ & $\begin{array}{l}\text { Mean } \\
\text { Rank }\end{array}$ \\
\cline { 2 - 4 } & Easy to find & 100 & 640,77 \\
\cline { 2 - 3 } & Aroma & 100 & 325,85 \\
\hline Colour & 100 & 617,26 \\
Duration & 100 & 532,28 \\
\hline Freshness & 100 & 442,16 \\
\hline Water contens & 100 & 563,37 \\
\hline Expire date & 100 & 623,34 \\
\hline Purpose & 100 & 398,73 \\
\hline Information & 100 & 407,90 \\
\hline Additional & 100 & 453,37 \\
esens & & \\
\hline Total & 1000 & \\
\hline
\end{tabular}

\section{Test Statistics ${ }^{a, b}$}

\begin{tabular}{|l|r|}
\hline & \multicolumn{1}{|c|}{ Import } \\
\hline Chi-Square & 139,305 \\
df & 9 \\
Asymp. Sig. &, 000 \\
\hline
\end{tabular}

a. Kruskal Wallis Test

b. Grouping

Variable: Atribut 